\title{
The Turning Point of Italian Scientific Pedagogy in The School of Maria Montessori and Giuseppina Pizzigoni
}

\author{
Sandra Chistolini, PhD \\ Università degli Studi Roma Tre, Italy
}

Doi:10.19044/ejes.v7no3a10 URL:http://dx.doi.org/10.19044/ejes.v7no3a10

\begin{abstract}
At the beginning of the $20^{\text {th }}$ century, there were several women in Italy, who gave pedagogy a new impulse. Among those women, two educationalists, Maria Montessori and Giuseppina Pizzigoni introduced new visions of the school by designing strategies that overcame the barriers to education. The first, with the structuring of a method, arose in Rome and has now spread throughout the world. The second was the creation of the Pizzigoni Renewed School in Milan. The Ministry of Education validated their proposals as innovative methods for all schools. In 1911, Pizzigoni's experimental method received official approval and, since then, teacher training courses were promoted. The enlightened spirits of these two pioneers led the Italian school towards a new deal. The search for a method was at the basis of the scientific and experimental turning point; the method also had to taken advantage of medicine and psychology, both relevant in the preparation of all teachers. This article focuses attention on the value of the scientific research conducted by Pizzigoni, less known internationally. Pizzigoni thought, built and defined the school and the method as a unique pedagogical act. She structured the curriculum for kindergarten and decidedly wished to turn the direction of elementary studies upside down: from Idealism to Positivism, from passivity to activity, from rigidity to creativity. In her mind children must be removed from the unhealthy places of the Milan suburbs and, instead, must be educated in a school open to the world. Hence the pedagogical elaboration of the concept of objective teaching as the keyword of the experimental method.
\end{abstract}

Keywords: School pedagogy, La Scuola Rinnovata, experimental method, objective teaching, outdoor education. 


\section{Introduction}

In $20^{\text {th }}$-century Italy, official pedagogy was male and official education was female: more males had the opportunity to become academics and the majority of the teachers in schools were women. In the 21st century, there has been an increase in the number of women in university chairs of General and Social Pedagogy and History of Pedagogy. The statistics of the Italian Ministry of Education, University and Research report 156 males and 222 females on December 31, 2019. The Italian school situation is still similar to the past, in the sense that the majority of teachers are represented by women. In the school system, there are 872,268 teachers; of these 159,741 were males and 712,527 females on August 31, 2018 (MIUR, 2019).

Female educators, mothers, teachers and female professors have represented the model of Italian culture until most recent years. Perhaps the most well-known case of the inversion of this trend is that of Montessori. She was a new woman for the times in which she lived, and made pedagogy the flag of female liberation, hereby justifying everything with science. On the other hand, university careers for women in pedagogy, particularly elementary school teachers, has always been difficult, since an educated woman could aspire at most to a permanent teaching position in school and most certainly not a university career. This is why we can say that, even until 1970, women encountered pedagogy being taught by men at the university and developed educational interventions in families and schools as educators and teachers. This situation changed after 1970 through student movements, mass university education, the liberalisation of study plans and the institution of new courses for degrees in Sociology and Psychology; all the above began competing against courses for degrees in Pedagogy that are notoriously more philosophical and thought of almost exclusively for persons wishing to teach. Thought of, that is, by men for women. In other words, the theory was a male thing and practice was a female thing.

The early $20^{\text {th }}$ century in Italy was in itself an era dedicated to women as regards education more than pedagogy. Rosa (1866-1951) and Carolina (1870-1945) Agazzi, Giuseppina Pizzigoni (1870-1947) and Maria Boschetti Alberti (1884-1951) were teachers and educators; unlike Maria Montessori (1870-1952), they did not believe so much in having to render a service to science as to serve childhood and adolescents moving towards adulthood, thus, conceiving the best education for developing the child. The different training of these women was unquestionably important in the subsequent development of feminine pedagogy and education (Chistolini, 2009, pp. 38-40).

The strong, tenacious routes, constants in education and feminine pedagogy are: the emergence of interest in education; autonomous pedagogic thought; setting up a school; the sensation of the idea; and the fame and persistence of the innovation. 


\section{The vision of two enlightened women}

The thought I would like to put forward considers two important examples of Montessori, which began with her experiment with "Casa dei bambini" (Home for Children) in Rome on 6 January 1907 and about which she wrote in Il Metodo della pedagogia scientifica (The Method of scientific pedagogy) in 1909. Above all, Montessori was a physician interested in pedagogy; she did not have a long, constant university career, but she was very well known as a speaker and for disseminating The Method and was known as "Doctor".

Pizzigoni was a teacher-educator, the "Lady", as she was called, who conceived and diffused a new school known as "La Rinnovata" (The Renewed School), still functioning in Milan today. Ms Pizzigoni conceived the fundamental guidelines for the school in 1907 and created an initial nucleus with them, as an experiment, in Ghisolfa in 1911. In the same year she illustrated La scuola elementare rinnovata secondo il metodo sperimentale (The Renewed school according to the experimental method) during a public Conference (Pizzigoni, (n. d., p. 37). In a short article in the "Pedagogic Journal" in 1909, Pizzigoni was able to show her interest in scientific and practical research (Pizzigoni, 1909, pp. 71-74).

In 1927, the Municipality of Milan promoted the development and expansion of the school according to the plan of the teacher; shortly thereafter, the Pizzigoni Work was set up (Opera Pizzigoni, 1934) as a non-profit organisation having the purpose of disseminating the method and programme, preparing teachers and assisting schools (Nicoli, 1947, pp. 141).

The principal reason of the literature I am proposing lies in the question Pedagogia maschile - educazione femminile? (Male pedagogy - female education?), the title of the European seminar Männliche Pädagogik weibliche Erziehung? carried out in Nuremburg on 21-23 January 2007, within the academic collaboration between Università "Roma Tre" and the University of Würzburg, Germany (Böhm, 2007, pp. 35-40).

However, the intellectual challenge is neither in the question nor the argument that may arise, but in the dash between the two terms. There is no alternative between pedagogy and education, just as there is no alternative between male and female. Both are necessary for properly educating a person. In particular, the theory of education, recognised in Christianity, and to which we refer, is based on the coherence of the person, who educates with the rationality of a man and fidelity of a woman. The fidelity of a man and rationality of a woman are not excluded, however, emphasis is placed on how the woman is in charge of the educational duties complemented with affectivity, sensitivity and love, much more than the man, who is totally intent on the rational process of his educational activity. Even if we do not like this casuistry, we cannot but confirm its relevance, not so much in terms of gender 
as in terms of the human condition, suspended among intelligence, willingness and feelings. Both are examples and role models for their children and both are figures required for the complete, harmonious growth of a child.

Male and female exist as gender distinctions from biological, cultural and social points of view. A man who leaves his job to raise his children and allows the woman, alone, to work, and a woman who takes on the male role model for her career, hereby completely neglecting her family, confirm the distinction between male and female, to the exasperation of social behaviour.

There are two levels: that of common people and that of specialists in education. There are parents who raise their children according to principles of goodness and honesty, freedom and responsibility, which they draw from their own religious and social education. They have never read books on pedagogy, nor do they look for the best method or the best teacher when they send their children to school. For them, the family educates before the school and the school should do its job, by teaching the necessities of cultural and social life.

If, on the other hand, we look at specialists in education, we see that they are quite careful about indicating exactly what to do to educate children, young people and adults. Specialists deduce the principles of education from theories worked up by other people and rarely experience the dilemmas of educating first-hand. The separation between academic training and school remains an open question. I teach general pedagogy in the graduate's course of teachers' training, but I cannot talk to school teachers and have to do the $a$ posteriori construction of a priori teaching. This means that the professor of general pedagogy is asked to insert general pedagogic reasoning - which gives scientific value to going to school - into didactic practice; the professor must make a deduction from an induction and present, in writing, the deduction prior to the induction.

\section{The emergence of scientific perspective in the study of the child}

Let us move on to our examples. Montessori was an extraordinary woman, a woman with a medical degree at a time when it was difficult for a woman to study, more difficult to attain a degree, and almost unthinkable to graduate in medicine, i.e. in a strictly male field of study. Furthermore, we do not get an image of Montessori as a woman, who was affectionate towards her own children, but rather of a doctor lecturing on the problem of education. Of course, the change from an educational approach, such as that of Pestalozzi, attentive to the role of the maternal figure, and an educational approach, such as that of Montessori, is quite evident. Pestalozzi did not eliminate the mother, but reinforced and enhanced her; in fact, he judged infanticide a social evil as a result of lack of education and opportunity for the instruction of women. Montessori was concerned with the affective role of women, being mainly 
directed at discovering a child that has a mind like a sponge; she did not neglect the context that makes the mind absorbent, but entrusted the entire task of education to the biopsychic and social structure. Social conditions must support education, not hinder it.

A recent paper written by authors Valeria P. Babini and Luisa Lama (2003) on the education of Maria Montessori emphasises as much the internationally famous educationalist as the figure of the new woman, both militant and emancipated. The transition from medicine to pedagogy was derived from the professional experience made by Montessori between the end of the $19^{\text {th }}$ century and the beginning of the $20^{\text {th }}$ : a heavily militant experience, in which medicine, social policies and practical feminism were interwoven, ending with the experiment with "Casa dei bambini", which can be considered the goal reached at the end of her educational path as a youth.

Maria Montessori was trained in medicine and then pedagogy, but her university studies were not completed, since she did not finish her period of teaching at the University of Rome. Her university activities were terminated in 1919, after non-attendances and leaves of absence. Teaching did not seem to interest her any longer.

What can be emphasised about this new, emancipated woman is that she was international. She used language that was easily understood by everyone. She introduced medicine into society, hereby assailing the education issue. She used the trampoline of science to disseminate ideas of social renewal in favour of education.

The question is, if Montessori was an educationalist or, rather, a physician, who had understood the importance of education to avoid illness, degeneration and deviancy and foreshadow a new humanity, liberated in both tradition and character. Social militancy could merge with an academic career through liberal teaching in anthropology, for which she presented her candidacy in 1902. Between 1902 and 1904, she enrolled in philosophy and attended courses by Labriola, Credaro and Barzellotti. She also attended the free courses in experimental psychology by De Sanctis, anthropometry by Vram and zoological anthropology by Moschen, who would then be on the Committee for free teaching. Labriola, Barzellotti and Credaro, who taught theoretical philosophy, the history of philosophy and pedagogy at the University of Rome, received her and allowed her to illustrate her view of education. Labriola was interested in the development of experimental psychology, Barzellotti in scientific research and Credaro watched, with interest, the pedagogy of Herbart for a scientific founding of educational knowledge. This is why Montessori responded to the impulse of giving substance to positive pedagogy, independent of philosophy. Credaro invited Montessori to give a conference on the subject of pedagogic anthropology (1903); the lessons were then collected in the renowned volume, Antropologia 
pedagogica, the fruit of four years of academic activity (Babini, Lama, 2003, p. 132). New pedagogy has a scientific basis; from biology one reaches the philosophical concept of becoming man.

\section{From the method to the school}

From a strictly academic point of view, Montessori cannot be considered an educationalist interested in being compared with the pedagogic culture of her time. Instead, she presented herself as an academic who wished to demonstrate how, to save humanity, one begins with the child and freedom of the human being and, more particularly and from direct experience, freedom for women.

Even without being a teacher of pedagogy at the University, Montessori used her culture and training to communicate to the world a new pedagogy that had the ideals of autonomy, independence, freedom and peace in common with the feminist movement. These ideals were better received in the United States, where, during those years, the progressive education of Parker and Dewey was being encountered (Tienken, 2017, pp. 124-125). The idea that philanthropic education should serve democracy and that there was hope in founding a new nation, by educating about childhood in the slums and the poor people in the most deprived areas, made one believe, even blindly, in the possible regeneration of the world. Montessori fostered this same humanitarian spirit and found fertile land, sowed by Dewey's ideas, in her conferences held in the United States.

Montessori felt the need to meet, as best she could, her mother's expectations, the wish to emerge as an original woman, the conviction that every social progress must come from science. Her mother was a well-read, liberal woman with a strong personality, who exercised such a great influence over her daughter that she convinced her to stay away from her son in order not to hinder her career. Her enrolment in medicine, research on the state of degradation of people with no education and affirmation as a free and independent person merged into the definition of the elements of the method. The citations by Montessori are pedagogic, but also medical, and, basically, her interest in children and the discovery of pedagogic anthropology were directly derived from her medical studies. At the moment in which she posed questions about the sense of life, and perhaps even about the method, she could not help but broach the pedagogic issue. She was not born into pedagogy, but reached it, hereby remaining a physician attentive to the structuring of knowledge into an organised form, hence, the method.

Pizzigoni is another story, despite being a contemporary of the other. At least three aspects are to be noted in the Pizzigoni experiment:

a) the critical issue of the background of the new school;

b) the comparative perspective in the renewal design; 
d) the social resonance and historic-cultural continuity of pedagogy.

\section{Between old and new school}

As for the critical issue, this refers to the Pizzigoni's description of schools of her times: "It all fails, because schools only concern themselves with intelligence and not with feelings and volition" (Pizzigoni 1956, p. 3), and again "I made attempts to modernise my school as much as I could, but many judged me a rather odd person. But my spirit was not daunted and, by directly studying the school, I had a quick, brief vision of what elementary school should be. At that time (in 1907), almost obeying an inner voice advising me, all in one go I laid out the fundamental points, on which the new school should be founded; I saw what the new environment should be; I saw how children would be able to move in it; I saw all the light and beauty that would come to the children's minds and spirits from a life of experience, and formed an ideal out of it" (Pizzigoni 1956, p. 18). Pizzigoni talks about the dream and utopia of the new school, thought out in a new environment and with new teachers. "Knowledge of both individual and group child psychology; aptitude to live the life of the world of little people; a mind trained in the knowledge of nature and social and national life; knowledge of method criterion for carrying out various sciences, and great interest in childhood, valued in itself, in its continuous development and in the future it will reach: in my opinion, these are the indispensable elements of training a teacher for a truly renewed primary school" (Pizzigoni 1956, p. 11).

Objective teaching, the experimental method, the psycho-physical experience of the pupil, workshops, classes in the open air and forming the character of the child are the original aspects of the Renewed School. This School opposes verbalism, studying for exams more than for life, and collecting words rather than observable facts. The reference to Leonardo and Galileo, as well as to Aristide Gabelli and Italian positivism, is clear (Roberto Ardigò, Saverio De Dominicis). Just as apparent is the appeal to idealism in recognising the pedagogic idea that releases the "universally implemented" pedagogic concept and founds the renewal on the "principle of truth", composed of ideas and things, body and spirit. In the introduction to the Fundamental Guidelines and Programmes, Pizzigoni writes, "The thinking in this work is the mirror of life of the pedagogic idea within my spirit, and is meant to be the story of new educational development..." (Pizzigoni 1922, p. 3 ). The building is the school that renders concrete the ideas feeding the conscience. "For me, new school is what has as much space as has the world and as many limits as has life. And, since life is analysis and construction, new school is what experiments and works" (Pizzigoni 1956, p. 293).

She criticises Herbart, who makes do with a teacher able to describe her experiences, whereas a teacher should reawaken the experiences of the 
pupils. She prefers Fröbel in Education of man that emphasises the importance of life in the open air, nature, travel and walks; one's own country is a "single all", and nature is a "continuous all" (Pizzigoni 1956, p. 26). As for Di Vincenzo Cuoco, Pizzigoni likes the specification of the aim of education that "more than presenting positive ideas, has to provide the mind with the aptitude to understand science" (Pizzigoni 1956, p. 27). In conclusion, after having reviewed these studies, Pizzigoni states, "How can I express the great joy of hearing the echo of my soul in these writings?" (G. Pizzigoni 1956, p. 28). And then, "This is how the concept of the duty of school is gradually completed and assumes the entirety of the great value in educating individuals and reforming society" (Pizzigoni 1956, p. 29).

And further, "Let us leave the world of words and enter the world of facts, that is my motto. I have conceived the school this way: facts teach; pupils experiment and learn; all teachers do is bring all the facts they find fundamentally educational into contact with the pupils, or the latter into contact with the former, and guide the minds of those who have to learn, so that the learning is orderly and becomes a source of life" (Pizzigoni 1929, pp. 10-11). The teacher and school prepare the conditions and ensure the possibilities of learning.

\section{School renovation architecture}

Having perceived the need to reform the school system, by renewing it from the inside, Pizzigoni studied the various experiences of the new school in the United States and Europe. She noticed how the U.S. presented itself as the land of true, modern, scientific pedagogy, against verbalism and in favour of personal and intellectual observation of the facts and phenomena. That school, totally aimed at solidity, seemed truly to reply to the needs of childhood. The teacher cited O. Buyse, the Hamptom school, the English open-air school (Letchwork in Garden City), Abbotsholme and workshops of practical pedagogy. Regarding Germany, she cited the Landerziehungsheime (1898) of Lietz, a $19^{\text {th }}$ century experiment in education towards citizenship. France was represented by the École des Roches (Edmond Demolins 18521907), Switzerland by the Waldschulen, Sweden by its workshops, and, for Russia, Tolstoi’s Jasnaja Poljana school.

Her studies preparing her to become a teacher and educational trips to Alsace, Germany, and Switzerland with faithful Maria Levi certainly showed an insatiable thirst for knowledge and the desire to compare her ideas and actions with the reform of the educational systems being created in European schools (Rossi Cassottana, 1988, 13). The coeducation of males and females and the opportunity of introducing sex education into schools (Rossi Cassottana, 1988, pp. 120-127) were among the innovations introduced by Pizzigoni. This was also probably the result of studies of experimental 
psychology and pedagogy and the awareness of the ongoing scientific debate about the value of differences. Thus, she confirmed the right and duty for the complete education of women in an era in which the wind of feminism, originating from the U.S., was still blowing weakly over Italy.

\section{The intuition of the experimental method}

With regard to the position of pedagogy, Luigi Romanini, introducing the edition of Linee fondamentali (Fundamental Guidelines) of 1956, wrote that it was more befitting to talk about Pizzigoni in terms of school pedagogy, that is, she induced the ideal and practical renewal of the school from the reality of the school, rather than from an academic general pedagogy that was constructed upon a preconceived idea and deduced the reality of the previous idea. That is to say, the need for a reversal from practice to theory (school pedagogy) and not from theory to practice (general pedagogy). Romanini concluded "If we keep in mind that, only over the last few years, after wandering through doctrinism, the concept of 'pedagogy of the school' is being systematically and academically attained. In the end, this concept must not surpass, but resolve 'general pedagogy' (just as school, now open to everyone, solves the education of children in civilised countries in the present social situation). Giuseppina Pizzigoni 'maestra' appears to deserve most of the credit for having had vocational insight and having prepared the way" (Pizzigoni 1956, p. XI).

The assessments made by G. Lombardo Radice about the Renewed School were addressed to the didactic inventiveness of the teachers and the inventiveness of the "work and expression of the pupils" (Rossi Cassottana, 1988, p. 23). Minister Luigi Credaro approved the Pizzigoni experiment and considered it a reform model for elementary school. The Gentile reform and elementary school programmes worked up by Lombardo Radice were abundantly inspired by the Renewed School. Examples in Italy and abroad have shown the dissemination of the method and today there are still exchanges between schools and teachers (Colombo, Manicone, Zuccoli, 2017, pp. 212-224).

\section{Conclusion}

The pedagogical production of the two women was very important in the sense of refining the method of teaching. Undoubtedly, the medical training of Montessori and teacher's training of Pizzigoni were determining factors in the repercussions of their scholastic and social engagement (ASOP, 2019). Both pay attention to the scientific and experimental perspective of teaching and learning process looking for the theoretical formulation of principles and concepts. They never left behind the aim of fixing the practice of education starting from the direct observation of facts and experience. They 
were convinced that theoretical concept must be validated in the field of practice, and the experience must renew the concepts. Their methods had also a severe impact on the social context. Education was in their minds the crucial point for the re-foundation of the society. Without a doubt, these women, who had an illuminated vision of education, contributed decisively to the transformation of the school committed in the liberation of the human being from the spiritual and material point of view. The revolutionary visions of Montessori and Pizzigoni gave the basis to the most modern shapes of the Italian school and also represent meaningful examples for schools of other countries (Böhm, 2000, 2015; Wisiak, 2016; Aktan-Acar, 2017).

\section{References:}

1. Aktan-Acar, E. (Ed.) (2017). Erken Çocukluk Eğitimi Mozaiği: Büyük Düşünceler/Fikirler, Modeller ve Yaklaşımlar. Ankara: Nobel Akademik Yayıncılık Eğitim Danışmanl.

2. Archivio storico dell'Opera Pizzigoni - ASOP (2019). L'Archivio ritrovato: le carte del Metodo Pizzigoni. Retrieved from http://www.operapizzigoni.it/1-archivio-storico

3. Babini, V. P. \& Lama, L., (2003). Una “donna nuova”. Il femminismo scientifico di Maria Montessori. Milano: Franco Angeli.

4. Böhm, W. (2000). ¿Más allá de María Montessori?. Santo Domingo, República Dominicana: Amigo del Hogar.

5. Böhm, W. (2007). Pedagogia al maschile. Educazione al femminile. Il Nodo. Scuole in rete, 10 (31), 35-40.

6. Böhm, W. (2015). Eine pädagogische Neuentdeckung: Giuseppina Pizzigoni und ihr Mailänder Kindergarten. Kinderleicht. Die Zeitschrift für engagierte Erzieherinnen und Erzieher, 2, 10-11.

7. Chistolini, S. (2009). L'asilo infantile di Giuseppina Pizzigoni. Bambino e scuola in una pedagogia femminile del Novecento. Milano: Franco Angeli.

8. Chistolini, S. (2015). Kindererziehung nach Giuseppina Pizzigoni. Gegenspielerin Maria Montessoris und Begründerin einer femininen Pädagogik, aus dem Italienischen und mit einem Vorwort von Winfried Böhm. Paderborn: Ferdinand Schöningh.

9. Colombo, R., Manicone, G., Zuccoli, F. (2017). Leggere con "metodo". Una riflessione sulla relazione tra il metodo Pizzigoni e l'apprendimento della lettura e scrittura.Form@re - Open Journal per la formazione in rete, 17 (2), 212-224.

10. Fondo Pizzigoni (2020). Materiali per le prove di livello dello sviluppo cognitivo: dimensione (3 anni). Retrieved from https://discovery.sba.uniroma3.it/primoexplore/fulldisplay?docid=39cab_almap2166202460002653\&context 
$=$ L\&vid=39CAB_V1\&lang=it_IT\&search_scope=ALL\&adaptor=Lo cal\%20Search\%20Engine\&tab=default_tab\&query=any,contains,fon do\%20pizzigoni, \%20prove\&offset $=0$

11. Fondo Pizzigoni (2020), Il Fondo Giuseppina Pizzigoni presso il Dipartimento di Scienze della Formazione. Roma: Università degli Studi Roma Tre. Retrieved from http://scienzeformazione.uniroma3.it/ricerca/progetti-diricerca/fondo-giuseppina-pizzigoni/

12. Laeng, M. (1997). Proposta di un manifesto per una pedagogia strutturalistica neomontessoriana. Proposed Manifesto for a neoMontessori Structuralist Pedagogy. Roma: Edizioni Opera Nazionale Montessori.

13. MIUR, Ministero dell'Istruzione, dell'Università e della Ricerca (2019, June 27). Portale Unico dei Dati della Scuola. Retrieved from https://dati.istruzione.it/espscu/index.html?area=anagScu.

14. Montessori, M. (1909). Il metodo della pedagogia scientifica applicato all'educazione infantile nelle case dei bambini. Città di Castello: S. Lapi.

15. Montessori, M. (1986). Educazione alla libertà. Leccese Pinna, M. L. (Ed.). Bari: Laterza.

16. Nicoli, P. F. (1947). Storia della Scuola Rinnovata. Fatti e documenti. Varese: La Tipografica Varese.

17. Opera Pizzigoni (1934). Statuto. Approvato con R. Decreto 28 settembre 1933, XI, n. 1460. Ufficio di Propaganda (Ed.). ReggioEmilia: Tipografia Ettore Ferraboschi.

18. Pizzigoni, G. (1909). L'istituto di psicologia e pedagogia sperimentale di Milano. Rivista pedagogica, 3 (1), 71-74.

19. Pizzigoni, G. (1913?!). La scuola elementare rinnovata secondo il metodo sperimentale. Milano: Paravia \& C.

20. Pizzigoni, G. (1922). Linee fondamentali e programmi della scuola elementare rinnovata secondo il metodo sperimentale. Milano: Paravia \& C.

21. Pizzigoni, G. (1929). L’insegnamento oggettivo. Estratto dalla "Rivista Pedagogica" diretta da Luigi Credaro. Anno XIII, fasc. 3-4. Milano: Tipografia della Scuola Rinnovata.

22. Pizzigoni, G. (1937). Scuola nuova maestro nuovo scolaro nuovo. Milano: Ufficio di Propaganda dell' «Opera Pizzigoni».

23. Pizzigoni, G. (1956). Linee fondamentali e programmi e altri scritti. Brescia: La Scuola.

24. Rossi Cassottana, O. (1988) ROSSI AND CASSOTTANA ARE TWO SURNAMES. Giuseppina Pizzigoni. Oltre il metodo: la “teorizzazione nascosta”. Brescia: La Scuola. 
25. Scocchera, A. (1997). Maria Montessori. Una storia per il nostro tempo. Roma: Edizioni Opera Nazionale Montessori.

26. Tienken, C.H. (2017). Defying standardization: Creating curriculum for an uncertain future. Lanham, MD: Rowman and Littlefield.

27. Wisiak, R. (2016). Giuseppina Pizzigoni. Freigeist, 44, 24-27 